\title{
Fourwing Saltbush Seed Yield and Quality: Irrigation, Fertilization, and Ecotype Effects
}

\author{
Joseph L. Petersen ${ }^{1}$ and Darrell N. Ueckert ${ }^{2}$ \\ Authors are ${ }^{1}$ Senior Research Associate and ${ }^{2}$ Regents Fellow and Professor, Texas Agricultural Experiment Station, \\ 7887 US Hwy 87 North, San Angelo, TX 76901-9714.
}

\begin{abstract}
Clones of superior pollen- and seed-producing plants of 4 fourwing saltbush (Atriplex canescens [Pursh] Nutt.) ecotypes were planted in a seed orchard in west-central Texas to determine if seed production and quality could be enhanced by irrigation and fertilization. Subplots of nitrogen (N) at $112 \mathrm{~kg} \cdot \mathrm{ha}^{-1}$, phosphorous (P) at $112 \mathrm{~kg} \cdot \mathrm{ha}^{-1}, \mathrm{~N}+\mathrm{P}$ at $112+112 \mathrm{~kg} \cdot \mathrm{ha}{ }^{-1}$, or no fertilizer were superimposed on irrigated or dryland main-plots. Neither irrigation nor fertilization affected estimated seed yields or utricle fill during the third growing season after planting. Fertilization did not affect seed germination of any of the saltbush ecotypes on irrigated plots or that of the 2 more xeric ecotypes (Grandfalls and Valentine) on dryland plots. Fertilizer N on dryland plots increased germination of the San Angelo ecotype, and N + P increased germination of the Texon ecotype. Estimated gross value of the first seed crop was about $\$ 4648 \cdot \mathrm{ha}^{-1}$ even though the superior reproductive traits of parental pistillate plants were poorly expressed by the clones. Fertilization did not affect estimated seed yields in irrigated plots, but $\mathrm{N}$ and $\mathrm{N}+\mathrm{P}$ increased seed yields in dryland plots in the fourth growing season. Fertilization effects on seed weights varied among irrigated and dryland plots and among saltbush ecotypes. Mortality of the shrubs during the period extending from 1988 to 1990 was not affected by irrigation or fertilization but increased among ecotypes as the xeric nature of their sites of origin increased and as the distance of their sites of origin from the seed orchard increased. Evidence from this study did not strongly support cloning, irrigation, or fertilization for improving seed harvests of fourwing saltbush in west-central Texas.
\end{abstract}

\section{Resumen}

Clones de plantas superiores en la producción de polen y semilla de 4 ecotipos de "Fourwing saltbush" (Atriplex canescens [Pursh] Nutt.) fueron plantados en un huerto para semilla en la parte centro-oeste de Texas para determinar si la producción de semilla y su calidad pudiera ser mejorada mediante irrigación y fertilización. Subparcelas de nitrógeno $(\mathrm{N})$ a $112 \mathrm{~kg} \cdot \mathrm{ha}^{-1}$, fósforo (P) a $112 \mathrm{~kg} \cdot \mathrm{ha}^{-1}, \mathrm{~N}+\mathrm{P}$ a $112+112 \mathrm{~kg} \cdot \mathrm{ha}^{-1}$ y sin fertilizante fueron sobrepuestas en parcelas irrigadas y sin irrigar que constituyeron las parcelas principales. Ni la fertilización ni el riego afectaron los rendimientos estimados de semilla o el llenado del utrículo durante la tercera estación de crecimiento después de la plantación. La fertilización no afectó la germinación de la semilla de ninguno de los ecotipos en las parcelas irrigadas o la de los dos ecotipos más xéricos (Grandfalls y Valentine) en las parcelas sin irrigación. En las parcelas sin riego, la fertilización $\mathrm{N}$ incrementó la germinación en el ecotipo San Angelo y la fertilización N + P incrementó la germinación del ecotipo Texon. El valor bruto estimado de la primer cosecha de semilla fue aproximadamente $\$ 4648 \cdot \mathrm{ha}^{-1}$ aunque las características reproductivas superiores de las plantas paternales pistiladas fueron pobremente expresadas por los clones. La fertilización no afectó los rendimientos estimados de semilla en las parcelas irrigadas, pero el $\mathrm{N}$ y $\mathrm{N}+\mathrm{P}$ incrementaron el rendimiento de semilla en las parcelas sin irrigación en la cuarta estación de crecimiento. Los efectos de la fertilización en el peso de la semilla variaron entre las parcelas irrigadas y sin irrigar y entre los ecotipos de "Fourwing saltbush". La mortalidad de los arbustos durante 1988-1990 no fue afectada por la irrigación o fertilización, pero se incrementó entre los ecotipos conforme la naturaleza xérica de sus sitios de origen aumentó y conforme se incrementó la distancia de sus sitios de origen de donde se colectó la semilla de la plantación. La evidencia de este estudio no soportan fuertemente la clonación, irrigación o fertilización para mejorar la cosecha de semilla del "Fourwing saltbush" en la región centro-oeste de Texas.

Key Words: Atriplex canescens, germination, mortality, seed production, seed weights, utricle fill

\section{INTRODUCTION}

Fourwing saltbush (Atriplex canescens [Pursh] Nutt.) is a desirable shrub native to many rangelands in western North America. The species is genetically diverse, adapted to a wide

Correspondence: Darrell N. Ueckert, Texas Agricultural Experiment Station, 7887 US Hwy 87 North, San Angelo, TX 76901-9714. Email: d-ueckert@tamu.edu

Manuscript received 22 March 2004; manuscript accepted 29 November 2004. variety of habitats, tolerates drought and temperature extremes, and generally retains its leaves during winter. It provides cover and forage for livestock and a variety of wildlife species (Plummer et al. 1966; Springfield 1970). It is widely used for revegetating depleted rangelands, disturbed sites, and saline soils. Several cultivars have been released for conservation uses (Noller et al. 1984). Fourwing saltbush seeds are harvested from wildland populations, but the quality and quantity of seeds vary greatly between harvest years and sites because of a complex of environmental and plant factors that 
are poorly understood (Springfield 1970; Stutz et al. 1975; Gerard 1978; Potter et al. 1986). Stutz et al. (1975) suggested that the low germinability in tetraploid fourwing saltbush populations was related to genetically induced abortion, but they recognized the influence of external factors such as weather conditions, insects, and fungi.

Flowering and seed production of many woody plants are stimulated by adequate moisture and soil nutrients (Krugman et al. 1974). Contour furrowing for conservation and concentration of water increased seed yields from native stands of 3 Atriplex spp. in a Utah study (Wein and West 1971). Data presented by Pendleton et al. (1992) indicated that irrigation could potentially enhance seed production of fourwing saltbush. They reported that $5 \mathrm{~L}$ of supplemental irrigation plant $^{-1} \cdot \mathrm{mo}^{-1}$ in a desert in northern Utah increased the percentage of pistillate plants of one fourwing saltbush ecotype that flowered (94\% for irrigated vs. $76 \%$ for nonirrigated) but decreased the percentage of pistillate plants of an ecotype from a more xeric area that flowered $150 \%$ for irrigated vs. $72 \%$ for nonirrigated). Irrigation increased pistillate inflorescence length, flowers pistillate inflorescence ${ }^{-1}$, and inflorescences pistillate plant ${ }^{-1}$ by $4 \%, 15 \%$, and $33 \%$, respectively, in the more mesic saltbush ecotype. Petersen et al. (1986) found that nitrogen $(\mathrm{N})$, phosphorus $(\mathrm{P})$, or $\mathrm{N}+\mathrm{P}$ fertilizer treatments did not affect survival of transplanted fourwing saltbush seedlings, but $\mathrm{P}$ fertilizer increased mean canopy height and diameter of the seedlings by $50 \%$ and $67 \%$, respectively, 17 months after transplanting. Although several studies have documented the effects of irrigation on survival and browse yield of fourwing saltbush (for example, see Cavazos Doria and Aldon 1993; Watson and O'Leary 1993, and references cited therein), we know of no prior research on the effects of irrigation or fertilization on fourwing saltbush seed yield or quality. Seed yields of Wyoming big sagebrush (Artemisia tridentata Nutt. ssp. wyomingensis [Beetle and Young]) were greater from plants growing on mined land than from those growing on adjacent rangeland, and fencing to prevent browsing of the inflorescences significantly increased seed yield, but not seed quality (Booth et al. 2003). However, the water conservation treatments studied (mulching and/or erecting windbreaks around individual plants) had only minor effects on seed yield or quality.

Some researchers have proposed that producing fourwing saltbush seeds in cultivated stands using applicable cultural practices would reduce the variation encountered in wildland stands, improve seed quality, and facilitate the maintenance of adequate seed supplies (Foiles 1974; Carlson 1984). It would also eliminate the inconvenience of locating acceptable wildland stands and obtaining permits or permission to harvest seeds (McArthur et al. 1978). Fourwing saltbush can be vegetatively propagated (cloned), and this facilitates the selection and increase of plants with desirable traits (Wiesner and Johnson 1977; McArthur et al. 1978; McArthur et al. 1984; Ueckert and Petersen 1991). McArthur et al. (1978) proposed a design for fourwing saltbush seed orchards and suggested that seed orchards could be a profitable enterprise on marginal agricultural lands. The objective of this study was to quantify the influence of irrigation, fertilization, and saltbush ecotype on plant growth, seed yield and quality, and longevity of 4 ecotypes of fourwing saltbush in a seed orchard in west-central Texas.

\section{METHODS AND MATERIALS}

\section{Study Site and Experimental Design}

A 1.5-ha seed orchard was established in April 1987 on a Rioconcho clay loam (fine, mixed, thermic Vertic Haplustolls) and Spur clay loam (fine-loamy, mixed, thermic Fluventic Haplustolls) soil complex near Carlsbad, in northwestern Tom Green County, Texas (lat $31^{\circ} 36^{\prime} \mathrm{N}$, long $100^{\circ} 39^{\prime} \mathrm{W}$ ). These soils formed on flood plains of the North Concho River. The 75- to 100-cm-thick, dark grayish-brown clay loam surface layer of these soils overlies a light-brown clay loam layer that extends to a depth of about $200 \mathrm{~cm}$ (Wiedenfeld and Flores 1976). Elevation of the study site is $610 \mathrm{~m}$, and mean annual precipitation is $53 \mathrm{~cm}$ (NOAA 2004). The site was graded for flood irrigation and divided into four 30-m-wide irrigation borders, 102 to $137 \mathrm{~m}$ long, separated by earthen berms.

Pistillate and staminate plants of 4 tetraploid (J. Barrow, USDA-Agricultural Research Service, personal communication, February 2004) western Texas ecotypes of fourwing saltbush that exhibited superior seed and pollen production in common nursery and field plantings at the Texas A\&M University Agricultural Research \& Extension Center near San Angelo, Texas, were propagated vegetatively in autumn 1986 from stem cuttings (Ueckert and Petersen 1991). The use of such clones should be advantageous because superior traits for seed orchard plants (seed and pollen production) show constancy from year to year (McArthur et al. 1978). The sites of origin of the 4 ecotypes were wildland populations near San Angelo (Tom Green County; lat $31^{\circ} 27^{\prime} \mathrm{N}$, long $100^{\circ} 30^{\prime} \mathrm{W}$ ), Texon (Reagan County; lat $31^{\circ} 14^{\prime} \mathrm{N}$, long $\left.101^{\circ} 40^{\prime} \mathrm{W}\right)$, Grandfalls (Pecos County; lat $31^{\circ} 15^{\prime} \mathrm{N}$, long $102^{\circ} 55^{\prime} \mathrm{W}$ ), and Valentine (Jeff Davis County; lat $30^{\circ} 37^{\prime} \mathrm{N}$, long $104^{\circ} 35^{\prime} \mathrm{W}$ ), Texas. These habitats and attributes of these ecotypes were described by Potter et al. (1986) and Petersen et al. (1987). Stem cuttings were maintained in the greenhouse during the winter, then hardened outdoors in full wind and sunlight before transplanting.

The seed orchard was laid out according to the design proposed by McArthur et al. (1978). About 1600 stem cuttings were transplanted on 3-m centers in rows spaced $3 \mathrm{~m}$ apart on 24 April 1987. Ten rows of saltbush stem cuttings were transplanted in each border, with rows aligned perpendicular to the prevailing southerly winds. One row of an equal and alternating mixture of staminate plants of the 4 ecotypes was planted on the windward (south) side of each border. A row of pistillate plants of each of the 4 ecotypes was transplanted on the leeward side of the staminate plants, with 2 sets of this arrangement in each border. Pistillate plants of the 4 ecotypes were alternated with respect to proximity to the windward row of staminate plants. All borders were irrigated once with about $10 \mathrm{~cm}$ of water (treated domestic sewage effluent) during summer 1987 to facilitate establishment of the stem cuttings. The study site was fenced to exclude livestock and deer.

The field experiment was arranged as a split-split plot design. Irrigation was the main-plot effect, fertilizer treatments were the subplot effect, and fourwing saltbush ecotypes were the sub-subplot effect. Irrigation treatments were assigned to the main-plots, with only 2 replications, because the effects of 
irrigation on seed yield and quality were expected to be substantial and easier to detect than those of fertilization (Gomez and Gomez 1984) and because the soils of the study site were very homogeneous. Space for the experiment was limited, and it did not seem prudent to increase replication by reducing plot size because plants near dikes in dryland plots might utilize water from adjacent irrigated plots via lateral roots. Two randomly selected borders were irrigated with about $10 \mathrm{~cm}$ water in May, July, August, and September 1989 and in June and July 1990. Two randomly selected borders were not irrigated. Rainfall was recorded at the study site with a rain gauge. Laboratory analysis of soil samples collected at the study site in July 1986 indicated very low levels $\left(6 \mathrm{mg} \cdot \mathrm{kg}^{-1}\right)$ of nitrate-nitrogen $\left(\mathrm{NO}_{3} \mathrm{~N}\right)$ and that P levels were very high $\left(45 \mathrm{mg} \cdot \mathrm{kg}^{-1}\right)$ but unavailable. Each main-plot was divided into 4 equal-size subplots for fertilizer treatments. Fertilizer treatments included broadcast applications of $\mathrm{N}$ at $112 \mathrm{~kg} \cdot \mathrm{ha}^{-1}$ as ammonium nitrate, $\mathrm{P}$ at $112 \mathrm{~kg} \cdot \mathrm{ha}^{-1}$ as concentrated superphosphate, $\mathrm{N}+\mathrm{P}$ at $112+112 \mathrm{~kg} \cdot \mathrm{ha}^{-1}$ on 14 April 1987, 18 May 1989, and 22 May 1990, or no fertilizer. The number of pistillate plants of each ecotype in each fertilizer subplot ranged from 14 to 26 . The nursery was cultivated 2 to 3 times in 1987 and 1988. Glyphosate [N(phosphonomethyl)glycine] and clopyralid (3,6-dichloro-2pyridinecarboxylic acid) herbicides were applied with a rope-wick applicator and/or backpack sprayers to control johnsongrass (Sorghum halepense [L.] Pers.) and broadleaf weeds, respectively, in 1989 and 1990. Carbaryl (1-naphthyl methylcarbamate) was aerially applied at $1.7 \mathrm{~kg} \mathrm{a.i.} \cdot \mathrm{ha}^{-1}$ in September 1988 to control blister beetles (Epicauta sp.), which were feeding heavily on the saltbush leaves. Composite soil samples were collected from $0-$ to $30-\mathrm{cm}$ and from 31- to 60-cm depths from each fertilizer treatment in March 1990 and were analyzed for nitrate-nitrogen by acid extraction and colorimetry and for $\mathrm{P}$ by ammonium acetate extraction and flame photometry by the Texas A\&M University Soil Testing Laboratory. Mortality of pistillate shrubs was calculated from data on the numbers of live plants in each fertilizer subplot in the autumns of 1988 and 1990. This experiment was not repeated at other locations or times because of the unavailability of land, irrigation water, and labor resources. The inferences presented herein apply specifically to the study site, the 4 fourwing saltbush ecotypes studied, and the environmental conditions that existed during this study.

\section{Field Data Collection}

Canopy heights and diameters of pistillate shrubs were recorded in the autumn of 1988 and of 1989. Canopy diameter was the average of the crown intercept measured parallel and perpendicular to the rows. Data were not collected from shrubs adjacent to borders between fertilizer treatments. Seed yield was estimated by a weight-estimate method. Each live pistillate plant was visually rated numerically for seed yield $(1=$ no or few seeds . . 5 = abundant seed) in the autumns of 1989 and 1990 by the same worker. A randomly selected pistillate plant within each rating score in each treatment combination was hand stripped of seed in December 1989 (160 total plants). Seeds were oven dried at $38^{\circ} \mathrm{C}$, dewinged with a modified hammermill, weighed, and placed in dry storage at room temperature until germination tests were performed. Data on de-winged seed yields $\left(\mathrm{g} \cdot\right.$ plant $\left.^{-1}\right)$ and canopy heights and diameters from the 160 hand-harvested plants were used to develop a prediction equation to estimate seed yields for all pistillate plants. Growth form of the shrubs was generally cylindrical; thus, shrub canopy volume was estimated by the equation:

$$
\mathrm{V}=\pi \mathrm{r}^{2} \mathrm{~h}
$$

where $\mathrm{V}=$ volume $\left(\mathrm{dm}^{3}\right), \quad \mathrm{r}=$ canopy radius $(\mathrm{dm})$, and $\mathrm{h}=$ canopy height $(\mathrm{dm})$. Regression analysis was used to establish the relationship between de-winged seed yield, seed production rating, and canopy volume:

$$
\log _{\mathrm{e}} \mathrm{Y}=-8.622+1.051 \mathrm{X}+1.252 \log _{\mathrm{e}} \mathrm{V}
$$

where $\mathrm{Y}=$ de-winged seed yield $\left(\mathrm{g} \cdot\right.$ plant $\left.^{-1}\right), \mathrm{X}=$ seed production rating, and $\mathrm{V}=$ canopy volume $\left(\mathrm{dm}^{3}\right)\left(r^{2}=0.785\right.$, $n=160)$. This equation was used to estimate seed yields from all pistillate plants that were not hand stripped of seed. The accuracy of the predictions was not tested, but we assumed this method was as accurate as the estimation and double sampling method (Pechanec and Pickford 1937) that is commonly used for estimating biomass of herbaceous vegetation. Seed yields were estimated for only 2 years, because traits for seed production show constancy from year to year among clones produced from parental plants that exhibit superior seed production (McArthur et al. 1978). Furthermore, a substantial decline in vigor and seed yield of the fourwing saltbush plants was visibly noticeable during the 1991 growing season (refer to section on plant mortality).

\section{Germination Trials}

Seeds harvested in December 1989 from large pistillate plants that had been rated 4 or 5 for seed production were subjected to 2 germination trials in October 1990 in separate environmental chambers (Puffer-Hubbard Model G1-10CT, Grand Haven, MI; and Sherer Environmental Model RI-25LTP, Ashville, NC). This subsampling criteria was imposed because of the large number of seeds necessary $\left(800 \cdot\right.$ plant $\left.^{-1}\right)$ for the germination trials and because it was felt that pistillate plants with low seedproduction potential would not be maintained in a seed orchard in which expensive cultural inputs were utilized. The percentage of pistillate plants of each ecotype in each experimental unit (fertilizer plot) sampled for seed germination and utricle fill ranged from $8 \%$ to $14 \%$. We recognize that seed viability varies considerably among pistillate plants of fourwing saltbush and that our subsampling procedure may not have provided the best possible estimate of the population means. There were 2 replications for each germination trial, each representing seeds from 2 individual plants within each treatment combination. A replication was the average of 4 Petri dishes, each with 50 whole, undamaged seeds (200 seeds replication ${ }^{-1}$ ). Each 50 -seed lot was weighed, then placed on a double layer of No. 3 filter paper in 9-cm-diameter Petri dishes, to which $9 \mathrm{~mL}$ of distilled water was added. The dishes were randomly placed on several layers of dampened blotter paper in covered glass boxes. The germination papers and blotter papers were maintained at saturation with distilled water throughout the trials. The glass boxes were placed in the environmental chambers at a constant $18^{\circ} \mathrm{C}$ with no light except 
Table 1. Monthly rainfall totals in 1989 and 1990 and long-term (30year) average monthly rainfall $(\mathrm{cm})$ at the fourwing saltbush seed orchard near Carlsbad, Texas.

\begin{tabular}{|c|c|c|c|}
\hline \multirow[b]{2}{*}{ Month } & \multicolumn{2}{|c|}{ Year } & \multirow{2}{*}{$\begin{array}{l}\text { Long-term } \\
\text { Average }^{1}\end{array}$} \\
\hline & 1989 & 1990 & \\
\hline & \multicolumn{3}{|c|}{ 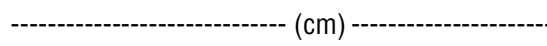 } \\
\hline January & 0.9 & 1.0 & 2.1 \\
\hline February & 9.7 & 4.8 & 3.0 \\
\hline March & 3.8 & 6.3 & 2.5 \\
\hline April & 0.9 & 8.0 & 4.1 \\
\hline May & 6.5 & 7.1 & 7.8 \\
\hline June & 10.7 & 0.0 & 6.4 \\
\hline July & 0.2 & 16.8 & 2.8 \\
\hline August & 2.2 & 4.6 & 5.2 \\
\hline September & 11.4 & 15.0 & 7.5 \\
\hline October & 0.0 & 7.0 & 6.5 \\
\hline November & 0.4 & 3.2 & 2.8 \\
\hline December & 0.8 & 0.8 & 2.4 \\
\hline Total & 47.4 & 74.5 & 53.1 \\
\hline
\end{tabular}

'Long-term average is based on National Oceanic and Atmospheric Administration (NOAA) records during the period from 1971 to 2000 for San Angelo, Texas, which is $30 \mathrm{~km}$ southeast of the study site.

during evaluations. Seeds were examined at 7-day intervals for 28 days and were recorded as germinated when radical length was greater than or equal to utricle length. Seed fill was determined for seeds that had not germinated after 28 days by clipping the end off the utricle and visually examining for a developed embryo. Total utricle fill for each seed replication was calculated by adding the percentage of seeds that germinated and the percentage of ungerminated seeds that contained developed embryos.

\section{Statistical Analyses}

Replication means for all dependent variables (plant heights and diameters, seed production ratings, estimated seed yields, utricle fill, germination, and plant mortality) were subjected to analysis of variance (ANOVA) (Gomez and Gomez 1984) to determine if independent variables (irrigation, fertilizer treatments, and ecotypes) had significant effects. Results from the 2 germination trials were similar; thus, the data were pooled for analysis. Treatment means were separated $(P \leq 0.05)$ by least significant difference, where appropriate, and $95 \%$ confidence intervals $(\mathrm{CI})$ were calculated for each treatment mean using the appropriate $t_{0.05}$ statistic and standard error of the mean. $F$ statistics, df, and $P$ values are presented in the tables for each ANOVA. Fertilizer $\times$ ecotype and irrigation $\times$ fertilizer $\times$ ecotype interactions were significant for seed weights and germination, so fertilizer effects on seed weights and germination were analyzed within each ecotype for each irrigation treatment. Irrigation $\times$ fertilizer and irrigation $\times$ ecotype interactions were significant for the 1990 seed production ratings, so fertilizer and ecotype effects were analyzed within each irrigation treatment. Simple linear correlation analysis (Gomez and Gomez 1984) was used to determine the closeness of association of shrub mortality from 1988 to 1990 with long-term average rainfall amounts at the sites of origin for the ecotypes $(n=4)$ and with
Table 2. Mean canopy heights and diameters $(\mathrm{cm})( \pm 95 \%$ confidence interval $[\mathrm{Cl}]$ ) of pistillate fourwing saltbush plants at the end of the 1988 and 1989 growing seasons after transplanting in April 1987 into an experimental seed orchard near Carlsbad, Texas, under selected irrigation and fertilization treatments. ${ }^{1}$

\begin{tabular}{|c|c|c|c|c|c|}
\hline \multirow{2}{*}{ Treatment } & & \multicolumn{2}{|c|}{1988} & \multicolumn{2}{|c|}{1989} \\
\hline & & Height & Diameter & Height & Diameter \\
\hline & & $-\cdots$ & --.--- & $--(\mathrm{cm})$ & - \\
\hline \multicolumn{6}{|l|}{ Irrigation $(n=32)$} \\
\hline Irrigated & & $68 \pm 4$ & $93 \pm 6$ & $124 \pm 2$ & $247 \pm 6$ \\
\hline \multirow[t]{4}{*}{ Dryland } & & $66 \pm 3$ & $88 \pm 5$ & $124 \pm 3$ & $231 \pm 10$ \\
\hline & $F$ statistic & 0.33 & 1.02 & 0.02 & 2.33 \\
\hline & df & 1,1 & 1,1 & 1,1 & 1,1 \\
\hline & $P$ & 0.67 & 0.50 & 0.92 & 0.37 \\
\hline Fertilizer $(n=16)$ & Rate $\left(\mathrm{kg} \cdot \mathrm{ha}^{-1}\right)$ & & & & \\
\hline None & 0 & $63 \pm 6$ & $82 \pm 11$ & $122 \pm 5$ & $226 b \pm 12$ \\
\hline Nitrogen $(\mathrm{N})$ & 112 & $72 \pm 4$ & $98 \pm 6$ & $127 \pm 4$ & $253 a \pm 8$ \\
\hline Phosphorus (P) & 112 & $66 \pm 4$ & $89 \pm 7$ & $121 \pm 4$ & $225 b \pm 14$ \\
\hline \multirow[t]{4}{*}{$\mathrm{N}+\mathrm{P}$} & $112+112$ & $68 \pm 4$ & $94 \pm 7$ & $127 \pm 3$ & $250 \mathrm{a} \pm 9$ \\
\hline & $F$ statistic & 2.55 & 2.31 & 2.82 & 7.86 \\
\hline & $\mathrm{df}$ & 3,6 & 3,6 & 3,6 & 3,6 \\
\hline & $P$ & 0.15 & 0.18 & 0.13 & 0.02 \\
\hline \multicolumn{6}{|l|}{ Ecotype $(n=16)$} \\
\hline San Angelo & & $70 \pm 6$ & $88 \pm 10$ & $130 a \pm 4$ & $248 a \pm 12$ \\
\hline Texon & & $62 \pm 4$ & $87 \pm 8$ & $121 b \pm 4$ & $233 b \pm 12$ \\
\hline Grandfalls & & $68 \pm 3$ & $89 \pm 5$ & $124 b \pm 3$ & $243 a \pm 11$ \\
\hline \multirow[t]{4}{*}{ Valentine } & & $69 \pm 5$ & $100 \pm 8$ & $122 b \pm 4$ & $231 b \pm 15$ \\
\hline & $F$ statistic & 2.12 & 2.47 & 7.94 & 6.19 \\
\hline & df & 3,24 & 3,24 & 3,24 & 3,24 \\
\hline & $P$ & 0.12 & 0.09 & 0.001 & 0.003 \\
\hline
\end{tabular}

${ }^{1}$ Means within a column and treatment group followed by similar lowercase letters are not significantly different according to least significant difference $\left(\mathrm{LSD}_{0.05}\right)$.

distances of the sites of origin of the ecotypes from the seed orchard $(n=4)$.

\section{RESULTS AND DISCUSSION}

\section{Growing Conditions}

Total rainfall of $66 \mathrm{~cm}$ during 1987 along with the single irrigation facilitated excellent establishment of fourwing saltbush transplants. Growing conditions were favorable, without irrigation, during both years in which saltbush seed production data were recorded. Rainfall during 1989 (47 cm; Table 1) was near normal for the site of origin of the San Angelo ecotype, but was $25 \%, 58 \%$, and $69 \%$ greater than normal for the sites of origin of the Texon, Grandfalls, and Valentine ecotypes, respectively. Rainfall during $1990(74 \mathrm{~cm})$ was $44 \%, 96 \%, 148 \%$, and $166 \%$ greater than normal for the sites of origin of the San Angelo, Texon, Grandfalls, and Valentine ecotypes, respectively.

\section{Plant Growth}

Neither irrigation, fertilization, nor saltbush ecotype affected shrub canopy heights or diameters at the end of the second 
Table 3. Mean seed production ratings, estimated de-winged seed yield $\left(\mathrm{g} \cdot\right.$ plant $\left.^{-1}\right)$, and utricle fill $(\%)( \pm 95 \%$ confidence interval $[\mathrm{Cl}])$ of fourwing saltbush plants in December 1989 in an experimental seed orchard near Carlsbad, Texas, under selected irrigation and fertilization treatments. 1

\begin{tabular}{|c|c|c|c|c|}
\hline Treatment & & $\begin{array}{c}\text { Seed } \\
\text { Production } \\
\text { Rating }^{2}\end{array}$ & $\begin{array}{l}\text { Estimated } \\
\text { De-winged } \\
\text { Seed Yield }\end{array}$ & $\begin{array}{c}\text { Utricle } \\
\text { Fill }\end{array}$ \\
\hline Irrigation $(n=32)$ & & & $\left(\mathrm{g} \cdot\right.$ plant $\left.^{-1}\right)$ & $(\%)$ \\
\hline Irrigated & & $2.8 \pm 0.2$ & $481 \pm 114$ & $35 \pm 4$ \\
\hline \multirow[t]{4}{*}{ Dryland } & & $3.0 \pm 0.1$ & $425 \pm 53$ & $34 \pm 4$ \\
\hline & F statistic & 0.14 & 0.06 & 0.04 \\
\hline & df & 1,1 & 1,1 & 1,1 \\
\hline & $P$ & 0.77 & 0.85 & 0.87 \\
\hline Fertilizer $(n=16)$ & Rate $\left(\mathrm{kg} \cdot \mathrm{ha}^{-1}\right)$ & & & \\
\hline None & 0 & $3.1 \pm 0.3$ & $475 \pm 115$ & $38 \pm 8$ \\
\hline Nitrogen (N) & 112 & $2.8 \pm 0.3$ & $475 \pm 133$ & $30 \pm 5$ \\
\hline Phosphorus (P) & 112 & $2.8 \pm 0.3$ & $381 \pm 133$ & $31 \pm 7$ \\
\hline \multirow[t]{4}{*}{$\mathrm{N}+\mathrm{P}$} & $112+112$ & $2.9 \pm 0.2$ & $482 \pm 147$ & $37 \pm 4$ \\
\hline & F statistic & 1.79 & 2.96 & 1.33 \\
\hline & $d f$ & 3,6 & 3,6 & 3,6 \\
\hline & $P$ & 0.25 & 0.12 & 0.35 \\
\hline \multicolumn{5}{|l|}{ Ecotype $(n=16)$} \\
\hline San Angelo & & $3.0 \mathrm{a} \pm 0.2$ & $515 a \pm 86$ & $33 b \pm 4$ \\
\hline Texon & & $3.1 \mathrm{a} \pm 0.4$ & $435 a b \pm 138$ & $40 a \pm 6$ \\
\hline Grandfalls & & $3.1 \mathrm{a} \pm 0.2$ & 578 a \pm 169 & $35 a b \pm 5$ \\
\hline \multirow[t]{4}{*}{ Valentine } & & $2.6 b \pm 0.2$ & $286 b \pm 56$ & $28 b \pm 7$ \\
\hline & F statistic & 4.53 & 5.64 & 4.49 \\
\hline & df & 3,24 & 3,24 & 3,24 \\
\hline & $P$ & 0.01 & 0.005 & 0.01 \\
\hline
\end{tabular}

\footnotetext{
${ }^{1}$ Values within a column and treatment group followed by similar lowercase letters are not different according to least significant difference $\left(\mathrm{LSD}_{0.05}\right)$.

${ }^{2}$ Seed production ratings were a visual estimate $(1=$ no or few seed $\ldots 5=$ abundant seed $)$ of seed yield in relation to plant canopy volume.
}

(1988) growing season (Table 2). Average canopy heights and diameters were 124 and $239 \mathrm{~cm}$, respectively, after 3 growing seasons. These values were similar to those for 3-year-old 'Rincon' fourwing saltbush in orchards in Colorado (Noller et al. 1984; McArthur et al. 1992). Shrub canopy diameters in 1989 were 24 to $28 \mathrm{~cm}$ greater for shrubs receiving $\mathrm{N}$ or $\mathrm{N}+\mathrm{P}$ fertilizer compared to those receiving only $\mathrm{P}$ or no fertilizer $(P=0.02)$ (Table 2). Mean canopy height of the San Angelo ecotype was 6 to $9 \mathrm{~cm}$ greater than that of the other 3 ecotypes $(P=0.001)$, and mean canopy diameters of the San Angelo and Grandfalls ecotypes exceeded those of the Texon and Valentine ecotypes 10 to $17 \mathrm{~cm}$ after 3 growing seasons $(P=0.003)$ (Table 2).

Growth of main stems of 16 accessions of fourwing saltbush in an irrigated nursery at Farmington, New Mexico (1 $660 \mathrm{~m}$ elevation) differed significantly over a 16 -month period (range from 14 to $60 \mathrm{~cm}$ ) (Fitzsimmons et al. 1998). The latitudes and elevations of the sites of origin of these accessions ranged from $31.2^{\circ} \mathrm{N}$ to $42.58^{\circ} \mathrm{N}$ and from 1 to $2800 \mathrm{~m}$, respectively. The accession exhibiting the greatest growth was from a site in Arizona at the same latitude as the study site $\left(36.52^{\circ} \mathrm{N}\right)$, but at
Table 4. Mean seed production ratings ${ }^{1}$ ( $\pm 95 \%$ confidence interval [CI]) of fourwing saltbush plants in December 1990 in an experimental orchard near Carlsbad, Texas, under selected irrigation and fertilization treatments. $^{2}$

\begin{tabular}{lccc}
\hline & & \multicolumn{2}{c}{ Irrigation Treatment } \\
\cline { 2 - 4 } Treatment & & Irrigated & Dryland \\
\hline Fertilizer $(n=8)$ & Rate $\left(\mathrm{kg} \cdot \mathrm{ha}^{-1}\right)$ & & \\
$\quad$ None & 0 & $2.2 \pm 0.7$ & $1.9 \mathrm{~b} \pm 0.5$ \\
Nitrogen (N) & 112 & $2.5 \pm 0.7$ & $2.2 \mathrm{a} \pm 0.6$ \\
Phosphorus (P) & 112 & $2.3 \pm 0.7$ & $1.5 \mathrm{c} \pm 0.5$ \\
$\mathrm{~N}+\mathrm{P}$ & $112+112$ & $2.2 \pm 0.7$ & $2.3 \mathrm{a} \pm 0.5$ \\
& F statistic & 2.67 & 8.58 \\
& $\mathrm{df}$ & 3,3 & 3,3 \\
& $P$ & 0.22 & 0.05 \\
Ecotype $(n=8)$ & & & \\
San Angelo & & $3.4 \mathrm{a} \pm 0.3$ & $2.8 \mathrm{a} \pm 0.5$ \\
Texon & & $2.6 \mathrm{~b} \pm 0.3$ & $2.0 \mathrm{~b} \pm 0.5$ \\
Grandfalls & & $1.7 \mathrm{c} \pm 0.2$ & $1.7 \mathrm{~b} \pm 0.3$ \\
Valentine & & $1.6 \mathrm{c} \pm 0.2$ & $1.6 \mathrm{~b} \pm 0.3$ \\
& & 51.91 & 25.82 \\
& & 3,12 & 3,12 \\
& $\mathrm{df}$ & 0.0001 & 0.0001 \\
\hline
\end{tabular}

${ }^{1}$ Seed production ratings were a visual rating $(1=$ no or few seed ...5 = abundant seed) of seed yield in relation to plant canopy volume.

${ }^{2}$ Values within a column and treatment group followed by similar lowercase letters are not significantly different according to least significant difference $\left(\mathrm{LSD}_{0.05}\right)$.

an elevation of $800 \mathrm{~m}$. The accessions exhibiting the least growth were from Sonora, Mexico $\left(31.2^{\circ} \mathrm{N}, 1-5 \mathrm{~m}\right)$. Variation in vegetative growth of our saltbush ecotypes was small because their sites of origin varied by only about $1^{\circ}$ in latitude and $4^{\circ}$ in longitude.

\section{Seed Production}

Seed production ratings and estimated seed yields in 1989 were similar among irrigation treatments and among fertilizer treatments (Table 3). Mean de-winged seed yield averaged over all treatment combinations was $453( \pm 62 \mathrm{CI}) \mathrm{g} \cdot \mathrm{plant}^{-1}$ (range 59 to 1230 ). Mean annual seed yield in a seed orchard in Utah ranged from $32 \pm 3$ to $211 \pm 11 \mathrm{~g} \cdot$ plant $^{-1}$ (McArthur et al. 1978). Estimated seed yields in our study ranged from 0 to $4278 \mathrm{~g} \cdot$ plant $^{-1}$ in 1989 , indicating that the superior traits for seed production seen in the parental plants were not consistently expressed by the clones. At the 2004 price for de-winged fourwing saltbush seeds in Texas $\left(\$ 13.23 \cdot \mathrm{kg}^{-1}\right)$ and adjusting for plant mortality, the estimated retail value of the 1989 seed crop was about $\$ 4648 \cdot \mathrm{ha}^{-1}$. The mean seed production rating for the Valentine ecotype was significantly $(P=0.01)$ lower than ratings for the other 3 ecotypes, and estimated de-winged seed yields of the San Angelo and Grandfalls ecotypes were 229 and $292 \mathrm{~g} \cdot$ plant $^{-1}$ greater $(P=0.005)$, respectively, than that of the Valentine ecotype (Table 3).

Seed production ratings in 1990 were similar among fertilizer treatments on the irrigated sites, but plants fertilized with $\mathrm{N}$ or $\mathrm{N}+\mathrm{P}$ produced more seeds $(P=0.05)$ than plants receiving no fertilizer or P under dryland conditions (Table 4). Laboratory analysis of composite soil samples collected in March 1990 (data 
Table 5. Mean percent (\%) germination ( $\pm 95 \%$ confidence interval $[\mathrm{Cl}]$ ) after 28 days of 4 western Texas ecotypes of fourwing saltbush seeds produced in 1989 under selected fertilizer treatments in an experimental seed orchard under irrigated and dryland conditions near Carlsbad, Texas, or under wildland conditions in $1981 .^{1}$

\begin{tabular}{|c|c|c|c|c|c|}
\hline \multicolumn{2}{|l|}{ Treatment } & \multicolumn{4}{|c|}{ Ecotype } \\
\hline \multirow[t]{2}{*}{ Fertilizer } & Rate & San Angelo & Texon & Grandfalls & Valentine \\
\hline & $\left(\mathrm{kg} \cdot \mathrm{ha}^{-1}\right)$ & \multicolumn{4}{|c|}{ 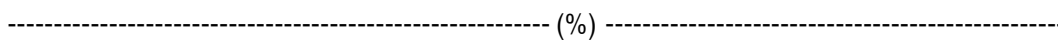 } \\
\hline None & 0 & $19 \pm 7$ & $32 \pm 5$ & $21 \pm 6$ & $13 \pm 12$ \\
\hline Nitrogen (N) & 112 & $14 \pm 5$ & $27 \pm 4$ & $22 \pm 10$ & $17 \pm 7$ \\
\hline Phosphorus (P) & 112 & $22 \pm 15$ & $30 \pm 17$ & $28 \pm 8$ & $14 \pm 10$ \\
\hline \multirow[t]{4}{*}{$\mathrm{N}+\mathrm{P}$} & $112+112$ & $19 \pm 14$ & $30 \pm 10$ & $25 \pm 3$ & $19 \pm 12$ \\
\hline & F statistic & 0.96 & 0.33 & 1.96 & 0.71 \\
\hline & $\mathrm{df}$ & 3,12 & 3,12 & 3,12 & 3,12 \\
\hline & $P$ & 0.44 & 0.81 & 0.17 & 0.57 \\
\hline None & \multicolumn{3}{|c|}{-------Dryland $1989(n=4)$--------. } & $16 \pm 8$ & $14 \pm 10$ \\
\hline Nitrogen (N) & 112 & $33 a \pm 10$ & $25 b \pm 8$ & $23 \pm 20$ & $21 \pm 12$ \\
\hline Phosphorus (P) & 112 & $7 b \pm 2$ & $15 c \pm 13$ & $34 \pm 25$ & $15 \pm 16$ \\
\hline \multirow[t]{5}{*}{$\mathrm{N}+\mathrm{P}$} & $112+112$ & $12 b \pm 9$ & $37 a \pm 11$ & $29 \pm 5$ & $21 \pm 12$ \\
\hline & F statistic & 12.10 & 9.52 & 2.02 & 1.05 \\
\hline & $d f$ & 3,12 & 3,12 & 3,12 & 3,12 \\
\hline & $P$ & 0.001 & 0.002 & 0.16 & 0.41 \\
\hline & & 45 & 27 & 31 & 44 \\
\hline
\end{tabular}

${ }^{1}$ Means within a column and irrigation treatment followed by similar lowercase letters are not different according to least significant difference $\left(\mathrm{LSD}_{0.05}\right)$.

${ }^{2}$ Adapted from Potter et al. (1986).

not shown) indicated that the concentration of $\mathrm{NO}_{3}-\mathrm{N}$ in the 0 to $30-\mathrm{cm}$ depth in $\mathrm{N}$-fertilized plots was greater on the dryland plots $\left(12-39 \mathrm{mg} \cdot \mathrm{kg}^{-1}\right.$ ) compared to the irrigated plots (6-7 $\left.\mathrm{mg} \cdot \mathrm{kg}^{-1}\right)$, but these values could not be compared statistically. The $\mathrm{N}$ fertilizer may have been leached to depths greater than 60 $\mathrm{cm}$ on irrigated plots or may have been more heavily utilized by the irrigated saltbush plants compared to the dryland plants.

In 1990, the San Angelo ecotype produced more seed than the Texon, Grandfalls, or Valentine ecotypes under irrigated and dryland conditions $(P=0.0001)$ (Table 4). Seed production ratings for the San Angelo and Texon ecotypes were about $20 \%$ and $30 \%$ greater, respectively, under irrigation compared to dryland conditions, whereas ratings for the Grandfalls and Valentine ecotypes were the same on irrigated and dryland plots. The San Angelo and Texon ecotypes were from relatively mesic environments $\left(53\right.$ and $38 \mathrm{~cm}$ rainfall $\cdot \mathrm{y}^{-1}$, respectively), whereas the Grandfalls and Valentine ecotypes came from more xeric environments $\left(30\right.$ and $28 \mathrm{~cm}$ rainfall $\cdot \mathrm{y}^{-1}$, respectively) (Petersen et al. 1987). Our 1990 seed production ratings (Table 4) supported the findings of Pendleton et al. (1992), whereas our 1989 data (Table 3) did not.

Seed production ratings for 1990 (Table 4) were generally lower than those for 1989 (Table 3) for all treatments. The seed orchard was browsed by sheep and goats during the winter of 1989-1990, but the effect of defoliation on seed production is nebulous. Briggs (1984) reported that fourwing saltbush seed production was unaffected by pruning of the plants, whereas Cibils et al. (2003) found that browsing by cattle increased the percentage of saltbush plants that did not produce flowers.
Above-average rainfall in 1990, heavy rainfall during pollination in 1990, or the heavy seed crop in 1989 may have negatively affected 1990 seed production. Noller et al. (1984) reported that seed production from cloned plants in a young orchard at Meeker, Colorado, varied considerably in consecutive years. Annual seed yield from a small seed orchard in Utah ranged from 54 to $483 \mathrm{~kg} \cdot \mathrm{ha}^{-1}$ over a 4 -year period (McArthur et al. 1978). Another possible explanation for the decline in seed production from 1989 to 1990 might have been the onset of a disease that eventually caused heavy mortality of all saltbush ecotypes in the orchard (refer to the section on plant mortality).

\section{Seed Germination}

There were significant irrigation $\times$ fertilizer $\times$ ecotype interactions for germination data from the 1989 seed crop. Average germination was $22 \%$, but germination varied from $4 \%$ to $49 \%$ among the plants from which seeds were harvested (data not shown). Almost two-thirds of the utricles that contained embryos (see Table 3) germinated during the 28-day trials. Monsen and McArthur (1985) reported 36\% germination of 'Rincon' fourwing saltbush seeds. Fertilization did not affect seed germination within any of the saltbush ecotypes on irrigated plots or that of the Grandfalls or Valentine ecotypes on dryland plots (Table 5). However, on dryland plots, fertilizer $\mathrm{N}$ increased $(P=0.001)$ germination of the San Angelo ecotype 16 to 26 percentage units compared to other fertilizer treatments, and $\mathrm{N}+\mathrm{P}$ increased germination of the Texon ecotype $(P=0.002)$ by 15 to 22 percentage units compared to other fertilizer treatments (Table 5). Fertilizer P decreased germination 
Table 6. Mean seed weights ( $\mathrm{g} \cdot 50^{-1}$ seeds) ( $\pm 95 \%$ confidence interval $[\mathrm{Cl}]$ ) of 4 western Texas ecotypes of fourwing saltbush produced under selected fertilizer treatments. Seeds were harvested in December 1989 from plants grown under irrigated and dryland conditions in an experimental seed orchard near Carlsbad, Texas. ${ }^{1}$

\begin{tabular}{|c|c|c|c|c|c|}
\hline \multicolumn{2}{|l|}{ Treatment } & \multicolumn{4}{|c|}{ Ecotype } \\
\hline \multirow[t]{2}{*}{ Fertilizer } & Rate & San Angelo & Texon & Grandfalls & Valentine \\
\hline & $\left(\mathrm{kg} \cdot \mathrm{ha}^{-1}\right)$ & \multicolumn{4}{|c|}{ 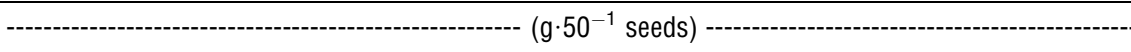 } \\
\hline None & 0 & $0.84 \mathrm{a} \pm 0.14$ & $0.88 \mathrm{a} \pm 0.24$ & $0.57 \pm 0.13$ & $0.54 \pm 0.21$ \\
\hline Nitrogen (N) & 112 & $0.56 \mathrm{~b} \pm 0.08$ & $0.49 \mathrm{c} \pm 0.17$ & $0.50 \pm 0.11$ & $0.70 \pm 0.36$ \\
\hline Phosphorus (P) & 112 & $0.65 b \pm 0.12$ & $0.49 c \pm 0.06$ & $0.64 \pm 0.18$ & $0.75 \pm 0.44$ \\
\hline \multirow[t]{4}{*}{$\mathrm{N}+\mathrm{P}$} & $112+112$ & $0.65 b \pm 0.08$ & $0.69 b \pm 0.07$ & $0.63 \pm 0.15$ & $0.64 \pm 0.18$ \\
\hline & F statistic & 12.26 & 15.06 & 2.00 & 0.82 \\
\hline & df & 3,12 & 3,12 & 3,12 & 3,12 \\
\hline & $P$ & 0.001 & 0.0002 & 0.17 & 0.51 \\
\hline None & 0 & $0.83 a \pm 0.33$ & $0.53 \pm 0.28$ & $0.46 b \pm 0.22$ & $0.45 \pm 0.04$ \\
\hline Nitrogen (N) & 112 & $0.49 b c \pm 0.07$ & $0.50 \pm 0.06$ & $0.59 a b \pm 0.03$ & $0.51 \pm 0.17$ \\
\hline Phosphorus (P) & 112 & $0.43 c \pm 0.04$ & $0.53 \pm 0.18$ & $0.76 a \pm 0.32$ & $0.47 \pm 0.03$ \\
\hline \multirow[t]{4}{*}{$N+P$} & $112+112$ & $0.67 b \pm 0.26$ & $0.68 \pm 0.11$ & $0.40 b \pm 0.06$ & $0.51 \pm 0.12$ \\
\hline & F statistic & 7.13 & 2.10 & 6.18 & 0.86 \\
\hline & df & 3,12 & 3,12 & 3,12 & 3,12 \\
\hline & $P$ & 0.005 & 0.15 & 0.009 & 0.49 \\
\hline
\end{tabular}

${ }^{1}$ Means within a column and irrigation treatment followed by similar lowercase letters are not different according to least significant difference $\left(\operatorname{LSD}_{0.05}\right)$.

of the Texon ecotype 10 to 22 percentage units compared to $\mathrm{N}$ and $\mathrm{N}+\mathrm{P}$ treatments $(P=0.002)$. These findings indicate that $\mathrm{N}$ or $\mathrm{N}+\mathrm{P}$ fertilization may enhance the seed germinability of fourwing saltbush ecotypes from mesic environments. Comparison of data from this germination trial with that from a trial conducted in July 1982 on seeds harvested in December 1981 at the sites of origin of these fourwing saltbush ecotypes (Table 5; from Potter et al. 1986) indicates that the quality of seeds from wildland harvests may be equal to or greater than that of seeds grown in a seed orchard with irrigation and/or fertilization.

\section{Utricle Fill}

Utricle fill of seeds produced in the orchard in 1989 averaged $34.5 \%$ (range, $12 \%-70 \%$ ) among the plants sampled. Our average seed fill was identical to that reported for a tetraploid population of wildland fourwing saltbush in Utah (Stutz et al. 1975), but only about half that reported for 'Rincon' fourwing saltbush (65\%) (Monsen and McArthur 1985). The plant-toplant variation was similar to that for pistillate clones of 'Rincon' fourwing saltbush grown in a seed orchard (Noller et al. 1984). Utricle fill of the 1989 seed crop was not affected by irrigation or fertilization treatments (Table 3). Seeds of the Texon ecotype contained $7 \%$ and $12 \%$ more $(P=0.01)$ embryos than the San Angelo and Valentine ecotypes, and the Grandfalls ecotype was intermediate between these 2 groups (Table 3 ). Low percentages of utricle fill occurred in several Australian Atriplex species grown under cultivated and irrigated conditions (Beadle 1952). Gerard (1978) concluded that cumulative precipitation and fourwing saltbush seed germination were not correlated but suggested that the amount of rainfall received during the growing season could influence fruit fill. Utricle fill partly depends on ratio and proximity of pistillate to staminate plants, wind direction and movement during flowering, and relative humidity (Gerard 1978; McArthur et al. 1984). Rows of pistillate plants in our study were $\leq 6 \mathrm{~m}$ from a row of staminate plants and $\leq 12 \mathrm{~m}$ leeward from a row of staminate plants during times of the prevailing southerly winds. Tetraploid populations of fourwing saltbush are inherently low in seed viability compared to diploids of the species, possibly as a result of a high proportion of nonviable gametes (Stutz et al. 1975).

\section{Seed Weights}

The main effects of irrigation and fertilization on seed weights could not be tested because of interactions with ecotypes. On irrigated plots, fertilization with $\mathrm{N}, \mathrm{P}$, or $\mathrm{N}+\mathrm{P}$ decreased seed weights of the San Angelo $(P=0.001)$ and Texon $(P=0.0002)$ ecotypes but did not affect seed weights of the Grandfalls or Valentine ecotypes (Table 6). On dryland plots, fertilization with $\mathrm{N}, \mathrm{P}$, or N + P decreased seed weights of the San Angelo ecotype $(P=0.005)$, and fertilization with $P$ increased seed weights for the Grandfalls ecotype $(P=0.009)$. The finding that fertilizer $\mathrm{N}$ on dryland plots decreased seed weight of the San Angelo ecotype (Table 6) while increasing seed germination (Table 5) indicated that seed weight and seed viability were not related. Fertilization did not affect seed weights of the Texon and Valentine ecotypes under dryland conditions (Table 6).

\section{Plant Mortality}

Mortality of fourwing saltbush from autumn 1988 to autumn 1990 averaged $12.75 \%$ and was similar among irrigation treatments and among fertilizer treatments (Table 7). Mortality of the 4 ecotypes was negatively associated with normal rainfall amounts at their sites of origin $(r=-0.93 ; n=4 ; P \leq 0.10)$. 
Table 7. Mean mortality (\%) ( $\pm 95 \%$ confidence interval $[\mathrm{Cl}])$ of fourwing saltbush from November 1988 to November 1990 grown under selected irrigation and fertilization treatments in an experimental seed orchard near Carlsbad, Texas. ${ }^{1}$

\begin{tabular}{|c|c|c|}
\hline Treatment & & Plant Mortality (\%) \\
\hline \multicolumn{3}{|l|}{ Irrigation $(n=32)$} \\
\hline Irrigated & & $10.6 \pm 2.7$ \\
\hline \multirow[t]{4}{*}{ Dryland } & & $14.9 \pm 5.7$ \\
\hline & F statistic & 0.39 \\
\hline & df & 1,1 \\
\hline & $P$ & 0.65 \\
\hline Fertilizer $(n=16)$ & Rate $\left(\mathrm{kg} \cdot \mathrm{ha}^{-1}\right)$ & \\
\hline None & 0 & $10.3 \pm 5.1$ \\
\hline Nitrogen (N) & 112 & $16.1 \pm 7.9$ \\
\hline Phosphorus (P) & 112 & $14.4 \pm 9.4$ \\
\hline \multirow[t]{4}{*}{$N+P$} & $112+112$ & $10.3 \pm 4.0$ \\
\hline & $F$ statistic & 0.56 \\
\hline & $d f$ & 3,6 \\
\hline & $P$ & 0.66 \\
\hline \multicolumn{3}{|l|}{ Ecotype $(n=16)$} \\
\hline San Angelo & & $4.4 \mathrm{c} \pm 2.8$ \\
\hline Texon & & $10.1 b c \pm 6.0$ \\
\hline Grandfalls & & $14.9 a b \pm 3.6$ \\
\hline \multirow[t]{4}{*}{ Valentine } & & $21.6 \mathrm{a} \pm 9.0$ \\
\hline & $F$ statistic & 9.76 \\
\hline & df & 3,24 \\
\hline & $P$ & 0.0002 \\
\hline
\end{tabular}

${ }^{1}$ Means within a treatment group followed by similar lowercase letters are not significantly different according to least significant difference $\left(\mathrm{LSD}_{0.05}\right)$.

Mortality was positively associated with distance of the sites of origin of the ecotypes from the seed orchard $(r=+0.99 ; n=4$; $P \leq 0.05)$. Mortality of the San Angelo ecotype (4.4\%), which originated nearest the seed orchard and in the most mesic environment, was significantly $(P=0.0002)$ lower than that for the Grandfalls (14.9\%) and Valentine (21.6\%) ecotypes, which originated in the most xeric environments and in the habitats most distant from the seed orchard. The more mesic San Angelo ecotype originated only about $23 \mathrm{~km}$ from the study site and was best adapted to the seed orchard environment. The more xeric Valentine ecotype from $400 \mathrm{~km}$ west of the study site was clearly least adapted to the seed orchard environment.

All fourwing saltbush ecotypes in the seed orchard suffered very heavy natural mortality during the period extending from 1991 to 1996, apparently as a result of a disease in the basal stems. The seed orchard was destroyed in 1998. Very heavy natural mortality also occurred in a nursery of these 4 ecotypes planted near San Angelo, Texas, in 1981 (Petersen et al. 1987), a nursery that was neither irrigated nor fertilized. Fourwing saltbush is naturally susceptible to basal decay disease in both plantations and natural populations, but this has not been seen as a serious problem by Atiplex researchers in other regions (E. D. McArthur, USDA-Forest Service, personal communication, February 2002). The brief life span of fourwing saltbush in this study did not seem sufficient to justify seed orchard enterprises at our study site, either with or without irrigation or fertilization.

\section{CONCLUSION}

Irrigation had no effect on vegetative growth, estimated seed yield, utricle fill, or plant mortality of 4 fourwing saltbush ecotypes. The finding that seed germination was not affected by fertilization on irrigated plots but was enhanced by $\mathrm{N}$ or $\mathrm{N}+\mathrm{P}$ fertilizer on dryland plots for 2 ecotypes indicates that irrigation may have nullified the potential benefits of $\mathrm{N}$ or $\mathrm{N}+\mathrm{P}$ fertilizer. Available water was probably not a limiting factor for seed yield or quality on dryland plots in this study. Fertilization had no biologically significant effects on vegetative growth of fourwing saltbush on either irrigated or dryland plots or on seed yield, utricle fill, plant mortality, or germination of seeds produced on irrigated plots. $\mathrm{N}$ or $\mathrm{N}+\mathrm{P}$ fertilizer may enhance germinability of seeds of ecotypes from mesic environments. Fertilizer effect on seed weights was nebulous. Small seed size associated with N fertilization of the San Angelo ecotype was also associated with greater seed germination; thus, seed size does not appear to be an important seed quality criteria. P may rarely be limiting for fourwing saltbush because of a mutualistic association with the fungus Aspergillus ustus, which colonizes the radicles of seedlings, solubilizes plant-unavailable forms of $\mathrm{P}$, and transfers $\mathrm{P}$ to saltbush roots (Barrow and Osuna 2002).

Our data indicate that selection of an adapted ecotype is more important for a seed orchard than is irrigation or fertilization. Plants of the ecotype that originated very close to the seed orchard were generally larger in size and had greater estimated seed yields and lower mortality than most of the other ecotypes. Constancy of superior reproductive traits of parental plants was not exhibited by their clones. Seed yield from clones ranged from 0 to $4278 \mathrm{~g} \cdot$ plant $^{-1}$. The disease-related plant mortality observed in this study demonstrates a pitfall of closely spaced monocultures. Plant and row spacings greater than $3 \mathrm{~m}$ and buffer strips of native vegetation between rows should be considered for seed orchards. Inferences that can be made from this study are limited by the lack of long-term data to establish consistent trends over time and different environments.

\section{LITERATURE CITED}

Barrow, J. R., and P. Osuna. 2002. Phosphorus solubilization and uptake by dark septate fungi in fourwing saltbush, Atriplex canescens (Pursh) Nutt. Journal of Arid Environments 51:449-459.

Beadle, N. C. W. 1952. Studies in halophytes. I. The germination of the seed and establishment of the seedlings of five species of Atriplex in Australia. Ecology 33:49-62.

Booth, D. T., AND E. E. Roos. 2003. Wyoming big sagebrush seed production from mined and unmined rangelands. Journal of Range Management 56: 542-546.

Briggs, J. A. 1984. Seed production of Atriplex canescens (Pursh) Nutt. in southern Arizona. In: A. R. Tiedemann, E. D. McArthur, H. C. Stutz, R. Stevens, and K. L. Johnson (ComPS.). Proceedings of the Symposium on the Biology of Atriplex and Related Chenopods; 2-6 May 1983; Ogden, UT. General Technical Report INT-172. US Department of Agriculture-Forest Service; Intermountain Forest and Range Experiment Station. p 187-190.

Carlson, J. R. 1984. Atriplex cultivar development. In: A. R. Tiedemann, E. D. McArthur, H. C. Stutz, R. Stevens, and K. L. Johnson (Comps.). Proceedings of the Symposium on the Biology of Atriplex and Related Chenopods; 2-6 May 
1983; Ogden, UT. General Technical Report INT-172. US Department of Agriculture-Forest Service. Intermountain Forest and Range Experiment Station. p 176-182.

Cavazos DoriA, J. R., and E. F. Aldon. 1993. Fourwing saltbush seedling survival using saline irrigation. Arid Soil Research and Rehabilitation 7:243-251.

CiBILS, A., D. M. SwIFT, AND R. H. HART. 2003. Changes in shrub fecundity in fourwing saltbush browsed by cattle. Journal of Range Management 56:39-46.

Fitzsimmons, K., C. Lovely, and E. Glenn. 1998. Growth differences among widely separated geographic accessions of fourwing saltbush (Atriplex canescens) in the Great Basin Desert, New Mexico, USA. Arid Soil Research and Rehabilitation 12:87-94.

Folles, M. W. 1974. Atriplex L.-saltbush. In: C. S. Shopmeyer (TECH. COORD.). Seeds of woody plants in the United States. Agriculture Handbook No. 450. Washington, DC: US Department of Agriculture-Forest Service. p 240-243.

GeRARD, J. B. 1978. Factors affecting fruit fill and seed germination of fourwing saltbush (Atriplex canescens [Pursh] Nutt.). In: D. N. Hyder [ed.]. Proceedings of the 1st International Rangeland Congress; 30-31 March 1984; Denver, C0. Society for Range Management. p 403-405.

Gomez, K. A., AND A. A. Gomez. 1984. Statistical procedures for agricultural research. 2nd ed. New York, NY: John Wiley \& Sons. 680 p.

Krugman, S. L., W. I. Stein, and D. M. Schmitt. 1974. Seed biology. In: C. S. Shopmeyer (TECH. COORD.). Seeds of woody plants in the United States. Agriculture Handbook No. 450. Washington, DC: US Department of Agriculture-Forest Service. p 5-40.

McArthur, E. D., A. C. Blauer, and G. L. Noller. 1984. Propagation of fourwing saltbush (Atriplex canescens [Pursh] Nutt.) by stem cuttings. In: A. R. Tiedemann, E. D. McArthur, H. C. Stutz, R. Stevens, and K. L. Johnson (comps.). Proceedings of the Symposium on the Biology of Atriplex and Related Chenopods; 2-6 May 1983; Ogden, UT. General Technical Report INT172. US Department of Agriculture-Forest Service. Intermountain Forest and Range Experiment Station. p 261-264.

McArthur, E. D., D. C. Freeman, L. S. Luckinbill, S. C. Sanderson, and G. L. Noller. 1992. Are trioecy and sexual lability in Atriplex canescens genetically based?: evidence from clonal studies. Evolution 46:1708-1721.

McArthur, E. D., A. P. Plummer, G. A. Van Epps, D. C. Freeman, and K. R. Jorgensen. 1978. Producing fourwing saltbush seed in seed orchards. In: D. N. Hyder [ed.]. Proceedings of the 1st International Rangeland Congress; 30-31 March 1984; Denver, C0. Society for Range Management. p 406-410.

Monsen, S. B., And E. D. McArthur. 1985. Factors affecting establishment of seeded broadleaf herbs and shrubs following fire. In: K. Sanders, J. Durham, and various agency editors [eds.]. Proceedings of Rangeland Fire Effects-A Symposium; 27-29 November 1984; Boise, ID. Idaho State Office, US Department of the Interior-Bureau of Land Management. p 112-124.

NOAA. 2004. Climatological data for Texas. National Climatic Data Center. Available at: http://www.ncdc.noaa.gov/oa/ncdc.html Accessed March 2004.
Noller, G. L., S. E. Stranathan, and E. D. McArthur. 1984. Establishment and initial results from a 'Rincon' fourwing saltbush (Atriplex canescens [Pursh] Nutt.) seed orchard. In: A. R. Tiedemann, E. D. McArthur, H. C. Stutz, R. Stevens, and K. L. Johnson (comps.). Proceedings of the Symposium on the Biology of Atriplex and Related Chenopods; 2-6 May 1983; Ogden, UT. General Technical Report INT-172. US Department of Agriculture-Forest Service. Intermountain Forest and Range Experiment Station. p 196-204.

Pechanec, J. F., and G. D. Pickford. 1937. A weight estimate method for determination of range or pasture production. Journal of the American Society of Agronomy 29:894-904.

Pendleton, B. K., D. C. Freeman, E. D. McArthur, and R. L. Pendleton. 1992. Life history features of three sexual morphs of Atriplex canescens (Chenopodiaceae) clones grown in a common garden. American Journal of Botany 79: 376-382.

Petersen, J. L., D. N. Ueckert, and R. L. Potter. 1986. Cultural practices for establishing fourwing saltbush within perennial grass stands. Journal of Range Management 39:460-463.

Petersen, J. L., D. N. Ueckert, R. L. Potter, and J. E. Huston. 1987. Ecotypic variation in selected fourwing saltbush populations in western Texas. Journal of Range Management 40:361-366.

Plummer, A. P., S. B. Monsen, and D. R. Christensen. 1966. Fourwing saltbusha shrub for future game ranges. Publication 66-4. Salt Lake City, UT: Utah State Department of Fish and Game. 12 p.

Potter, R. L., D. N. Ueckert, J. L. Petersen, and M. L. McFarland. 1986. Germination of fourwing saltbush seeds: interaction of temperature, osmotic potential, and $\mathrm{pH}$. Journal of Range Management 39:43-46.

SpRINGFieLD, H. W. 1970. Germination and establishment of fourwing saltbush in the southwest. Research Paper RM-55. Fort Collins, CO: US Department of Agriculture-Forest Service. Rocky Mountain Forest and Range Experiment Station. $48 \mathrm{p}$.

Stutz, H. C., J. M. Melby, And G. K. Livingston. 1975. Evolutionary studies of Atriplex. a relic gigas diploid population of Atriplex canescens. American Journal of Botany 62:236-245.

Ueckert, D. N., and J. L. Petersen. 1991. Selecting Atriplex canescens for greater tolerance to competition. Journal of Range Management 44:220-222.

Watson, M. C., and J. W. O'Leary. 1993. Performance of Atriplex species in the San Joaquin Valley, California, under irrigation and with mechanical harvests. Agriculture, Ecosystems and Environment 43:255-266.

Wein, R. W., and N. E. West. 1971. Phenology of salt desert plants near contour furrows. Journal of Range Management 24:299-304.

Wiedenfeld, C. C., And P. H. Flores. 1976. Soil survey of Tom Green County, Texas. Temple, TX: US Department of Agriculture-Soil Conservation Service. College Station, TX: Texas Agricultural Experiment Station. $186 \mathrm{p}$.

Wiesner, L. E., And W. J. Johnson. 1977. Fourwing saltbush (Atriplex canescens) propagation techniques. Journal of Range Management 30:154-156. 